\title{
Impact of Bio- and Chemical Fertilization on Growth, Yield, Essential Oil and Chemical Composition of Fennel (Foeniculum vulgare Mill.) Plant
}

\section{Omniea M Allam ${ }^{*}$, Sohair E Hassan ${ }^{1}$, Awaad M Kandeel', Ahmed N Abdelhamed ${ }^{1}$, Abdallah S Korayem ${ }^{2}$}

1- Agric Horticulture Department, Faculty of Agriculture, Ain Shams University, P.O. Box 68, Hadayek Shoubra 11241, Cairo, Egypt

2- Agric. Microbiology Department, Faculty of Agriculture, Ain Shams University, P.O. Box 68, Hadayek Shoubra 11241, Cairo, Egypt

* Corresponding author: omnieamohsen@agr.asu.edu.eg

DOI:10.21608/ajs.2021.77849.1383

Received 27 May, 2021 ; Accepted 23 October, 2021

\section{Keywords:}

Fennel, Bio-fertilization, Azotobacter chroococcum, Bacillus circulans, Vesicular-arbuscular mycorrhiza, Essential oil

\begin{abstract}
Pot experiment was carried out in seventeen levels of fertilization to evaluate the effect of the bio-fertilizer mixture alone or in combination with chemical fertilizer (NPK) on Fennel (Foeniculum vulgare Mill). Biofertilizer was a mixture of Azotobacter chroococcum, Bacillus circulans and Vesicular-arbuscular mycorrhiza. Results indicated that use of bio-fertilizer at $3.75 \mathrm{ml} /$ pot four times with $25 \%$ of NPK gave the highest significant values of vegetative growth, yield parameters, and also NPK uptake; however, fertilizing with bio-fertilizers without NPK application showed the lowest significant values in the two experimental seasons. The same addition of biofertilizer gave the highest significant values of total microbial count of soil and increased cumulative $\mathrm{CO}_{2}$; whereas addition of $100 \%$ NPK gave the lowest significant values in both seasons. The full dose of NPK significantly increased volatile oil percentage while the addition of bio-fertilizer only significantly decreased it in both seasons. GC analysis of essential oil showed that the highest percentage of anethol $(12.77 \%)$ was obtained by applying $3.75 \mathrm{ml} /$ pot bio-fertilizer added one time $+25 \%$ NPK and decreased estragole $(72.78 \%)$.
\end{abstract}

\section{Introduction}

Originally, the Mediterranean region was considered as the native environment to the fennel (Foeniculum vulgare Mill.) which is an annual plant, belonging to the Apiaceae family, soon after, fennel was naturalized and cultivated worldwide (Lim 2013).

In this regard, Egypt is deemed one of the most important producers for aromatic and medicinal crops in the Middle East because it enjoys a suitable environment to cultivate these crops
(Elsabawy 2012). Specifically, Egypt comes fifth among countries, producing fennel fruits as it produces $3.1 \%$ of total amounts of world exports. (Trade Map 2019). The Egyptian fennel is characterized by good yields (Massoud 1992) and superior to sweet or German variety (Ghazal and Shahhat 2012). Moreover, the content of oxygenated compounds in the local variety is higher than the German one (Osman 2009). Fennel is utilized as an estrogenic, lactagogue, antioxidant, diuretic, immunological booster, and dyspepsia treatment in Egyptian traditional medicine. (Ebeedet al 2010). Carminative, aromatic, antispasmodic, anti- 
inflammatory, and emmenagogue are all properties of fennel seed. It relieves gas and colic while also boosting digestion and appetite, it also increases the flow of milk in nursing mothers. The main constituents of fennel seed essential oil are trans-anethole, fenchone, estragol (methyl chavicol), and limonene. The oil can be used to treat flatulence or in toothpaste, soaps, air fresheners etc. Moreover, if it is used externally, it can eases muscular and rheumatic pain (Lim 2013).

Being an important product with many uses, it is essential to try to increase the production of fennel in Egypt by using a good type and rationalizations of fertilizers which can help the plants absorb the available forms of nitrogen, phosphorus and potassium from soil, which are mostly exist in unattainable forms to the plants. These three elements are crucial to the growth and development of the plant; however, the use of chemical fertilizers is expensive and has bad effect on the soil and plants. For example, high rates of $\mathrm{N}$ fertilizer applied to soils are harmful for any living creature (Barabasz et al 2002) and the high rates of $\mathrm{P}$ fertilizer that are added to the soil can precipitate and become fixed in the soil by 7590\% causing long-term impacts on the environment.

Bio-fertilizers can help the plants absorb the N, $\mathrm{P}$ and $\mathrm{K}$ elements in a more efficient and safe way. Bio-fertilizers are products containing living cells of diverse types of microorganisms, which can added to plant surface or seeds. They can help to colonize the rhizosphere or the interior of the plant promoting growth by converting nutritionally important elements from unavailable to available form. Bio-fertilizers also can protect the environment and be ecofriendly fertilizer because it increases sustainability of soil, which ultimately leads to the reduction of damages caused by chemical fertilizer (Mohammadi and Sohrabi 2012). Furthermore, applying bio-fertilizers enhancing the use efficiency of nutrients and plant growth in comparison to fully fertilized controls, while lowering fertilizer inputs by up to half dose without incurring yield loss (da Costa et al 2013, Good and Beatty 2011, Hayat et al 2010).

On the other hand, excessive use of chemical fertilizers can led to many issues such as the huge waste of mineral resources. In addition, millions of tons of chemical nutrients that are added to soil continuously are not absorbed by plants. It is reported that up to $50 \%$ of $\mathrm{N}$ and $90 \%$ of $\mathrm{P}$ are not absorbed by the crops which can ultimately ran away to the atmosphere or water sources, thus, causing the global warming gases and salinization in soil (da Costa et al 2013, Simpson et al 2011).

Bio-fertilizers can be divided into many microorganisms such as nitrogen-fixing bacteria, phosphate solubilizing microorganisms (PSMs) and potassium solubilizing microbes (KSMs). First, the most common species of nitrogen-fixing bacteria inhabiting many soils around the world from the genus Azotobacter is A. chroococcum (Mahato et al 2009). It is the most common type of free-living heterotrophic and non-symbiotic nitrogen-fixing bacteria found in neutral or alkaline soils (Wani et al 2016). They provide large amounts of nitrogen to non-leguminous plants (Aasfar et al 2021) when nitrogen is converted to ammonia by them which is then absorbed by plants (Prajapati et al 2008). Second, the phosphate solubilizing microorganisms (PSMs) can be used as biofertilizers to enhance the plant growth due to its capabilities of hydrolyzing organic and inorganic phosphorus compounds from insoluble compounds and provides an ecofriendly and economical saving to overcome the low availability of $\mathrm{P}$ in the soil (Kalayu 2019, Sharma et al 2013).The Mycorrhizal symbiosis, a type of PSMs, plays an effective role in promoting plant growth by obtaining of Phosphorus and other mineral nutrients from the soil, bioremediation, and providing defensive mechanism to the host plant against harmful pathogens (Aggarwal et al 2011). Third, Potassium is very tightly bound to soil, so the use of potassium solubilizing microbes as biofertilizer will be enhancing potassium availability to plants and their absorption by plant roots and become environment friendly than application of chemical $\mathrm{K}$ applied fertilizers (Padhan et al 2019). A type of KSMs used is Bacillus circulans of Bacillus species, which are a silicate solubilizing bacterium that enhances potassium availability to crops from insoluble $\mathrm{K}$ sources, thus, improving crop yield and decreasing chemical fertilizers additions (Khalil et al 2018, Padhan et al 2019).

This study aims to evaluate the ability of biofertilizer mixture and rationalization of mineral fertilization to enhancing the production of fennel and reduce chemical fertilizer application, as well as, to increase anethole as an active ingredient instead of estragole (which is an undesirable component).

\section{Materials and Methods}

Pot experiment was carried out at the experimental farm of Faculty of Agriculture, Ain Shams University, Cairo, Egypt during the two successive seasons of 2018/2019 and 2019/2020.Fennel (Foeniculum vulgare Mill) fruits were sown on the $28^{\text {th }}$ Oct, of both 
seasons in 30 diameter plastic pots filled with clean and washed sand in combination with compost at the ratio 3:1. Compost obtained from the plant Department of Faculty of Agriculture, Ain Shams University, Cairo, Egypt. The chemical analysis of the used compost is shown in Table $\mathbf{1}$.

\subsection{Chemical fertilizers}

Fully recommended dose of mineral fertilizers NPK were $300 \mathrm{Kg} /$ fed calcium-superphosphate $\left(15.5 \% \mathrm{P}_{2} \mathrm{O}_{5}\right)$ which was added during the preparation of the soil, $300 \mathrm{Kg} /$ fed ammonium nitrate $\left(33.5 \% \mathrm{NH}_{4} \mathrm{NO}_{3}\right)$ and $100 \mathrm{Kg} /$ fed potassium sulphate $\left(48 \% \mathrm{~K}_{2} \mathrm{O}\right)$ were added in two equal doses. The first one was added 45 days starting from the appearance of the real leaves and the second was added 45 days after the first one (Osman 2009). The quantity per plant was calculated as follows: $16.66 \mathrm{~g} / \mathrm{plant}$ calcium-superphosphate $(15.5 \%$ $\left.\mathrm{P}_{2} \mathrm{O}_{5}\right), 16.66 \mathrm{~g} /$ plant ammonium nitrate $(33.5 \%$ $\mathrm{NH}_{4} \mathrm{NO}_{3}$ ) and $5.55 \mathrm{~g} /$ plant potassium sulphate $\left(48 \% \quad \mathrm{~K}_{2} \mathrm{O}\right)$ and added at the same dates mentioned above.

\subsection{Bio-fertilizer}

The strains of bio-fertilizer used were Azotobacter chroococcum $\left(10^{8} \mathrm{CFU} / \mathrm{ml}\right.$.), Bacillus circulans $\left(10^{8} \mathrm{CFU} / \mathrm{ml}\right.$.) and (VAM) Vesiculararbuscular mycorrhiza (200 spores/ml.). These strains were mixed in equal parts and added to the wet soil surface beside plants in liquid form once, twice, three, or four times. All inoculants were provided by Bio-fertilizer Unit, Fac. of Agric., Ain Shams Univ., Cairo, Egypt.

\subsection{Experimental Treatments}

Mixture of three bio-fertilizer strains added once (after one month of planting), twice (first addition was a month after sowing and the second was a month after the first addition), three times (first addition was a month after sowing and a month separates the addition and another), or four times (first addition was a month after sowing and a month separates the addition and another) in proportions as follow:
$5 \mathrm{ml} /$ pot bio-fertilizer only.

$3.75 \mathrm{ml} /$ pot bio-fertilizer with $25 \%$ of the recommended dose of NPK.

$2.5 \mathrm{ml} /$ pot bio-fertilizer with $50 \%$ of the recommended dose of NPK.

$1.25 \mathrm{ml} /$ pot bio-fertilizer with $75 \%$ of the recommended dose of NPK.

Control (Full dose of NPK as recommended doses).

The experiment was carried out in a completely randomized design with four replicates; each replicate contained 5 plants in 17 treatments $(17 \times 4 \times 5=340$ plants).

\subsection{Data recorded}

The number of main branches per plant and the number of umbels per plant were recorded after the full blooming. Fruit yield per plant $(\mathrm{g})$ and seed index (weight of 100 fruits $(\mathrm{g})$ ) were recorded at the end of experiment.

\subsubsection{Percentage of essential oil}

Hydro distillation is used to extract the essential oil from fruits according to the method described in (Pharmacopoeia 1963). Volatile oil percentage was calculated $(\mathrm{v} / \mathrm{w})$ and then kept at the refrigerator till $\mathrm{GC}$ analysis.

\subsubsection{Determination of essential oil constituents by GC analysis}

The volatile oil constituents were separated using Ds Chrom 6200 Gas Chromatograph equipped with a flame ionization detector. The condition of analysis was as follows:

The chromatography apparatus was supplied with capillary column DB-WAX 122-7032 polysillphenylene-siloxane $30 \mathrm{~m} \times 0.25 \mathrm{~mm}$ ID $\times 0.25 \mu \mathrm{m}$ film. The ramp of the temperature program increase with a rate of $13^{\circ} \mathrm{C} / \mathrm{min}$ from $60^{\circ} \mathrm{C}$ to $220^{\circ} \mathrm{C}$. The rates of flow of gases were nitrogen at $1 \mathrm{ml} / \mathrm{min}$, hydrogen at $3 \mathrm{ml} / \mathrm{min}$, and $330 \mathrm{ml} / \mathrm{min}$ for air. The temperatures of the detector and injector were $280^{\circ} \mathrm{C}$ and $250^{\circ} \mathrm{C}$, respectively.

Table 1. Chemical analysis of the used compost

\begin{tabular}{|l|l|l|l|l|l|l|l|l|l|}
\hline $\mathbf{P}^{\mathbf{H}}$ & $\mathbf{E C}(\mathbf{d s} / \mathbf{m})$ & Density $\left(\mathbf{K g} / \mathbf{m}^{\mathbf{3}}\right)$ & Moisture \% & O.M \% & O.C \% & N\% & P\% & K\% & $\begin{array}{l}\mathbf{C}: \mathbf{N} \\
\text { ratio }\end{array}$ \\
\hline 7 & 2.18 & 747 & 20.29 & 33.93 & 19.73 & 1.18 & 0.49 & 0.29 & 16.72 \\
\hline
\end{tabular}




\subsubsection{Chemical analysis}

\subsubsection{Determination the uptake of nitrogen, phosphorus and potassium}

Estimating the percentages of nitrogen, phosphorus, and potassium:

The chemical analysis was performed on dried herb samples at $70^{\circ} \mathrm{C}$ in forced air oven. The three elements were determined in the acid digested solution. Total nitrogen content was estimated by micro-Kjeldahl method, phosphorous concentration was estimated by colorimeter method (ammonium molybdate) using spectrophotometer according to (Okalebo et al 2002) and atomic absorption spectrophotometer was used for the determination of potassium concentration (Chapman and Pratt 1961).

Total uptake of nitrogen, phosphorous, and potassium was calculated according to (Sharma et al 2012) through the following equation:

Uptake of $\mathrm{N} / \mathrm{P} / \mathrm{K}\left(\mathrm{Mg} \mathrm{g}^{-1}\right.$ dry weight $)=$ nutrient percentage $\times$ dry matter

\subsubsection{Microbial studies}

Microbiological analysis of rhizosphere of fennel pot plants soil apart was done at the flowering stage and included the following measurements:

1- Total count of bacteria (TCB) was counted on Bunt and Rovira medium (Bunt and Rovira 1955). 2-cumulative $\mathrm{CO}_{2}$ : in each incubation bottle which contained the soil we placed vials containing $5-\mathrm{ml}$ of $1 \mathrm{M} \mathrm{NaOH}$ for 24 hours and then we add $0.5 \mathrm{M} \mathrm{BaCl}_{2}$ solution to trapped the $\mathrm{CO}_{2}$ in the $\mathrm{NaOH}$ and the total $\mathrm{C}$ of the trapped $\mathrm{CO}_{2}$ was measured by titrating against $0.1 \mathrm{M} \mathrm{HCl}$ using a phenolphthalein indicator and calculate the cumulative $\mathrm{CO}_{2}-\mathrm{C}$ as the sum of $\mathrm{CO}_{2}-\mathrm{C}$ effluxes $(\mathrm{mg}$ C/g) (Zibilske 1994).

\subsection{Statistical analysis}

The statistical analysis was performed using the CoStat Package Program (Version 6.303; CoHort Software, USA). The analysis of variance was used to examine the data (ANOVA). Duncan's Multiple Range Test was used to compare the discrepancies between data means. All statistical determinations were made at $\mathrm{P} \leq 0.05$.

\section{Results and Discussion}

Data in Table 2 showed that addition of $3.75 \mathrm{ml}$. of bio-fertilization mixture four times $+25 \%$ NPK gave the best results for the number of branches per plant, and umbels number per plant in both seasons, however adding the same treatment but three times, and adding $1.25 \mathrm{ml}$ bio once with $75 \%$ NPK showed non-significant difference between them for umbels number in the second season only. The addition of 5 $\mathrm{ml}$. of bio-fertilizer alone regardless of the times number of addition gave the lowest value with nonsignificant differences between them in the first and the second seasons.

Data in Table 3 showed that the inoculation with $3.75 \mathrm{ml}$. of bio-fertilizer added four times and apply $25 \%$ of NPK gave the highest fruit yield/plant, and highest seed index in both seasons. There was no statistically significant difference between this treatment and the addition of $2.5 \mathrm{ml}$. of bio added three or four times $+50 \%$ of NPK for fruit yield in the first season only. There wasn't a significant effect between this treatment and the treatments of $3.75 \mathrm{ml}$. bio added three times $+25 \%$ NPK and $2.5 \mathrm{ml}$. of bio added three times $+50 \%$ of NPK in both seasons for seed index. In both seasons the addition of $5 \mathrm{ml}$. of bio-fertilizer only gave the lowest fruit yield/plant and seed index with non-significant differences between the numbers of additions.

Data in Table 4 indicate that the various fertilization treatments had a significant effect on Nitrogen, and Phosphorus uptake ( $\mathrm{Mg} \mathrm{g}^{-1}$ dry weight) both seasons. The addition of $3.75 \mathrm{ml}$. bio added four times + 25\% NPK leads to the highest nitrogen and phosphorous uptake rate for the first and the second season. The addition of $5 \mathrm{ml}$. of bio-fertilizer only leads to the lowest nitrogen and phosphorous uptake rate in both seasons with a non-significant difference between the numbers of additions.

The previous results indicated an increase in vegetative growth and fennel yield. This increment may be due to an increase in essential nutrient uptake by the plant. The nitrogen uptake increasing maybe because of Azotobacter chroococcum which improves the growth of root and uptake of plant nutrients (Babalola 2010), addition due to better accelerated bacterial activity which leads to increased nitrogen fixation by converted atmospheric nitrogen to ammonia and the production of different growth hormones by them and their ability to produce a large amount of amino-acid like Glutamic acid and Lysine(González-López et al 2005) which leads to controlling the enhanced of root development and plant growth specifically vegetative 
Table 2. Effect of inoculation with mixture of Azotobacter chroococcum, Bacillus circulans and VAM per pot either separate or in combination with chemical fertilizer on number of branches/plant and umbels number/plant of fennel, during 2018/2019 and 2019/2020 seasons

\begin{tabular}{|c|c|c|c|c|}
\hline \multirow{2}{*}{ Treatments } & \multicolumn{2}{|c|}{ Number of branches/plant } & \multicolumn{2}{|c|}{ Umbels number/plant } \\
\hline & 2018/2019 & $2019 / 2020$ & $2018 / 2019$ & $2019 / 2020$ \\
\hline Control (100\%NPK) & $4.66 \mathrm{e}$ & $5.8 \mathrm{abc}$ & $7.1 \mathrm{ab}$ & $7.39 \mathrm{ab}$ \\
\hline T1 (5 ml.bio*1) & $3.97 \mathrm{f}$ & $3.18 \mathrm{~d}$ & $4.07 \mathrm{f}$ & $4.30 \mathrm{~d}$ \\
\hline T2 $\left(5 \mathrm{ml} . \mathrm{bio}^{2}\right)$ & $3.41 \mathrm{fg}$ & $2.79 \mathrm{~d}$ & $3.93 \mathrm{f}$ & $3.95 \mathrm{~d}$ \\
\hline $\mathbf{T 3}\left(5 \mathrm{ml}^{\mathrm{bio}}{ }^{3}\right)$ & $2.95 \mathrm{~g}$ & $3.22 \mathrm{~d}$ & 4.16 ef & $4.58 \mathrm{~d}$ \\
\hline T4 $\left(5 \mathrm{ml} . \mathrm{bio}^{4}\right)$ & $3.5 \mathrm{fg}$ & $3.41 \mathrm{~d}$ & $5.12 \mathrm{de}$ & $4.93 \mathrm{~cd}$ \\
\hline T5 (3.75 ml. bio ${ }^{1}+25 \%$ NPK $)$ & $5.1 \mathrm{cde}$ & $5.20 \mathrm{bc}$ & $5.8 \mathrm{~cd}$ & $6.12 \mathrm{bc}$ \\
\hline T6 (3.75 ml. bio $^{2}+25 \%$ NPK $)$ & $5.06 \mathrm{de}$ & $5.05 \mathrm{c}$ & $6.1 \mathrm{bcd}$ & $6.74 \mathrm{ab}$ \\
\hline T7 (3.75 ml. bio $^{3}+25 \%$ NPK $)$ & $6 a b$ & $5.72 \mathrm{abc}$ & $6.83 \mathrm{abc}$ & $7.75 \mathrm{a}$ \\
\hline T8 $\left(3.75\right.$ ml.bio $\left.{ }^{4}+25 \% \mathrm{NPK}\right)$ & $6.41 \mathrm{a}$ & $6.38 \mathrm{a}$ & $7.62 \mathrm{a}$ & $8.01 \mathrm{a}$ \\
\hline T9 $\left(2.5 \mathrm{ml} . \mathrm{bio}^{1}+50 \% \mathrm{NPK}\right)$ & 5.36 bcde & $5.55 \mathrm{abc}$ & $7 \mathrm{ab}$ & $7.15 \mathrm{ab}$ \\
\hline $\mathbf{T 1 0}\left(2.5 \mathrm{ml} . \mathrm{bio}^{2}+50 \% \mathrm{NPK}\right)$ & $5.80 \mathrm{abc}$ & $5.88 \mathrm{abc}$ & $6.8 \mathrm{abc}$ & $7.08 \mathrm{ab}$ \\
\hline T11 $\left(2.5 \mathrm{ml} . \mathrm{bio}^{3}+50 \% \mathrm{NPK}\right)$ & $5.87 \mathrm{ab}$ & $5.78 \mathrm{abc}$ & $6.66 \mathrm{abc}$ & $7.26 \mathrm{ab}$ \\
\hline T12 $\left(2.5 \mathrm{ml} . \mathrm{bio}^{4}+50 \% \mathrm{NPK}\right)$ & $5.86 \mathrm{ab}$ & $5.66 \mathrm{abc}$ & $6.62 \mathrm{abc}$ & $7.61 \mathrm{ab}$ \\
\hline $\mathbf{T 1 3}$ (1.25 $\mathrm{ml}^{\left.. \mathrm{bio}^{1}+75 \% \mathrm{NPK}\right)}$ & $5.43 \mathrm{bcd}$ & $5.31 \mathrm{bc}$ & $6.61 \mathrm{abc}$ & $7.93 \mathrm{a}$ \\
\hline T14 (1.25 ml.bio ${ }^{2}+75 \%$ NPK $)$ & $6 a b$ & $6.13 \mathrm{ab}$ & $7.18 \mathrm{ab}$ & $6.80 \mathrm{ab}$ \\
\hline T15 (1.25 ml.bio ${ }^{3}+75 \%$ NPK $)$ & $5.88 \mathrm{ab}$ & $6.15 \mathrm{ab}$ & $6.75 \mathrm{abc}$ & $7.08 \mathrm{ab}$ \\
\hline T16 (1.25 ml.bio $\left.{ }^{4}+75 \% \mathrm{NPk}\right)$ & 5.25 bcde & $6.08 \mathrm{ab}$ & $6.5 \mathrm{abc}$ & $7.36 \mathrm{ab}$ \\
\hline
\end{tabular}

${ }^{1}$ once ${ }^{2}$ twice ${ }^{3}$ three times ${ }^{4}$ four times first addition was a month after sowing, and a month separates the addition and another.

"bio-fertilizer.

Numbers followed by the same letter in the same columns are not significantly different at 5\% DMRT.

Table 3. Effect of inoculation with mixture of Azotobacter chroococcum, Bacillus circulans and VAM per pot either separate or in combination with chemical fertilizer on fruit yield/plant (g) and seed index of fennel, during 2018/2019 and 2019/2020 seasons

\begin{tabular}{|c|c|c|c|c|}
\hline \multirow{2}{*}{ Treatments } & \multicolumn{2}{|c|}{ fruit yield / plant (g) } & \multicolumn{2}{|c|}{ Seed index } \\
\hline & 2018/2019 & $2019 / 2020$ & 2018/2019 & $2019 / 2020$ \\
\hline Control (100\% NPK) & $11.87 \mathrm{~b}$ & $11.87 \mathrm{ab}$ & $1.4 \mathrm{abc}$ & 1.27 bcde \\
\hline $\mathbf{T 1}\left(5 \mathrm{ml}^{\mathrm{b}} \mathrm{bio}^{* 1}\right)$ & $5.22 \mathrm{~cd}$ & $5.47 \mathrm{de}$ & $1.29 \mathrm{bcd}$ & $1.21 \mathrm{de}$ \\
\hline $\mathbf{T} 2\left(5 \mathrm{ml} \cdot \mathrm{bio}^{2}\right)$ & $6.69 \mathrm{c}$ & $6.11 \mathrm{cde}$ & $1.23 \mathrm{~cd}$ & $1.18 \mathrm{e}$ \\
\hline T3 $\left(5 \mathrm{ml} \cdot \mathrm{bio}^{3}\right)$ & $4.62 \mathrm{~cd}$ & $4.70 \mathrm{e}$ & $1.35 \mathrm{abcd}$ & 1.27 bcde \\
\hline T4 $\left(5 \mathrm{ml} . \mathrm{bio}^{4}\right)$ & $2.20 \mathrm{~d}$ & $4.13 \mathrm{e}$ & $1.22 \mathrm{~d}$ & 1.25 cde \\
\hline T5 (3.75 ml.bio ${ }^{1}+25 \%$ NPK $)$ & $14.10 \mathrm{ab}$ & $10.56 \mathrm{ab}$ & $1.39 \mathrm{abcd}$ & $1.28 \mathrm{bcde}$ \\
\hline T6 (3.75 ml.bio ${ }^{2}+25 \%$ NPK) & $13.91 \mathrm{ab}$ & $10.03 \mathrm{ab}$ & $1.35 \mathrm{abcd}$ & $1.33 \mathrm{abc}$ \\
\hline T7 (3.75 ml.bio $^{3}+25 \%$ NPK) & $16.55 \mathrm{ab}$ & $10.50 \mathrm{ab}$ & $1.48 \mathrm{a}$ & $1.36 \mathrm{ab}$ \\
\hline T8 $\left(3.75{\left.\mathrm{ml} . \mathrm{bio}^{4}+25 \% \mathrm{NPK}\right)}\right.$ & $17.23 \mathrm{a}$ & $12.81 \mathrm{a}$ & $1.49 \mathrm{a}$ & $1.41 \mathrm{a}$ \\
\hline T9 (2.5 ml. bio ${ }^{1}+50 \%$ NPK $)$ & $14.98 \mathrm{ab}$ & $9.13 \mathrm{abc}$ & $1.43 \mathrm{ab}$ & $1.23 \mathrm{cde}$ \\
\hline T10 (2.5 ml. bio $\left.^{2}+50 \% \mathrm{NPK}\right)$ & $14.25 \mathrm{ab}$ & $12.49 \mathrm{ab}$ & $1.32 \mathrm{abcd}$ & $1.33 \mathrm{abc}$ \\
\hline T11 (2.5 ml. bio $^{3}+50 \%$ NPK $)$ & $17.10 \mathrm{a}$ & $12.51 \mathrm{ab}$ & $1.47 \mathrm{a}$ & $1.41 \mathrm{a}$ \\
\hline T12 (2.5 ml. bio $\left.{ }^{4}+50 \% \mathrm{NPK}\right)$ & $17.05 \mathrm{a}$ & $8.73 \mathrm{bcd}$ & $1.36 \mathrm{abcd}$ & $1.30 \mathrm{bcd}$ \\
\hline T13 (1.25 ml.bio $^{1}+75 \%$ NPK $)$ & $13.05 \mathrm{ab}$ & $11.39 \mathrm{ab}$ & $1.38 \mathrm{abcd}$ & $1.24 \mathrm{cde}$ \\
\hline T14 (1.25 ml.bio ${ }^{2}+75 \%$ NPK $)$ & $14.79 \mathrm{ab}$ & $10.05 \mathrm{ab}$ & $1.41 \mathrm{abc}$ & $1.32 \mathrm{abc}$ \\
\hline $\mathbf{T 1 5}\left(1.25 \mathrm{ml}^{\mathrm{bio}}{ }^{3}+75 \% \mathrm{NPK}\right)$ & $16.30 \mathrm{ab}$ & $11.31 \mathrm{ab}$ & $1.42 \mathrm{ab}$ & 1.27 bcde \\
\hline T16 (1.25 ml.bio $4+75 \% \mathrm{NPk})$ & $13.34 \mathrm{ab}$ & $11.73 \mathrm{ab}$ & $1.31 \mathrm{abcd}$ & 1.29 bcde \\
\hline
\end{tabular}

${ }^{1}$ once ${ }^{2}$ twice ${ }^{3}$ three times ${ }^{4}$ four times first addition was a month after sowing, and a month separates the addition and another.

"bio-fertilizer.

Numbers followed by the same letter in the same columns are not significantly different at 5\% DMRT. 
Table 4. Effect of inoculation with Azotobacter chroococcum, Bacillus circulans and VAM per pot either separate or in combination with chemical fertilizer on Nitrogen and Phosphorus uptake ( $\mathrm{gg} \mathrm{g}^{-1} \mathrm{dry}$ weight) of fennel, during 2018/2019 and 2019/2020 seasons

\begin{tabular}{|c|c|c|c|c|}
\hline \multirow{2}{*}{ Treatments } & \multicolumn{2}{|c|}{ Nitrogen uptake $\mathrm{Mg} \mathrm{g}^{-1}$ dry weight } & \multicolumn{2}{|c|}{ Phosphorus uptake $\mathrm{Mg} \mathrm{g}^{-1}$ dry weight } \\
\hline & 2018/2019 & $2019 / 2020$ & 2018/2019 & $2019 / 2020$ \\
\hline Control (100\% NPK) & 0.159 abcd & $0.264 \mathrm{bc}$ & $0.037 \mathrm{abc}$ & 0.031 abcde \\
\hline T1 (5 ml.bio $\left.{ }^{* 1}\right)$ & $0.101 \mathrm{~cd}$ & $0.103 \mathrm{i}$ & $0.026 \mathrm{c}$ & $0.016 \mathrm{~g}$ \\
\hline $\mathbf{T} 2\left(5 \mathrm{ml}^{\mathrm{bio}}{ }^{2}\right)$ & $0.117 \mathrm{bcd}$ & $0.159 \mathrm{gh}$ & $0.033 \mathrm{abc}$ & $0.027 \mathrm{def}$ \\
\hline $\mathbf{T 3}\left(5 \mathrm{ml}^{\mathrm{bio}}{ }^{3}\right)$ & $0.138 \mathrm{bcd}$ & $0.117 \mathrm{hi}$ & $0.033 \mathrm{abc}$ & $0.021 \mathrm{fg}$ \\
\hline T4 $\left(5 \mathrm{ml} . \mathrm{bio}^{4}\right)$ & $0.080 \mathrm{~d}$ & $0.095 \mathrm{i}$ & $0.029 \mathrm{bc}$ & $0.016 \mathrm{~g}$ \\
\hline T5 (3.75 ml. bio $+25 \%$ NPK $)$ & 0.164 abcd & 0.194 efg & $0.044 \mathrm{abc}$ & $0.023 \mathrm{efg}$ \\
\hline T6 (3.75 ml. $\left.\mathrm{bio}^{2}+25 \% \mathrm{NPK}\right)$ & 0.142 abcd & $0.217 \mathrm{cdef}$ & $0.037 \mathrm{abc}$ & $0.029 \mathrm{cdef}$ \\
\hline T7 (3.75 ml. bio $^{3}+25 \%$ NPK $)$ & $0.189 \mathrm{abc}$ & $0.172 \mathrm{fg}$ & $0.048 \mathrm{abc}$ & $0.029 \mathrm{cdef}$ \\
\hline T8 (3.75 ml.bio $\left.{ }^{4}+25 \% \mathrm{NPK}\right)$ & $0.234 \mathrm{a}$ & $0.317 \mathrm{a}$ & $0.058 \mathrm{a}$ & $0.039 \mathrm{a}$ \\
\hline T9 $\left(2.5\right.$ ml. bio $^{1}+50 \%$ NPK$)$ & $0.187 \mathrm{abc}$ & $0.220 \mathrm{cdef}$ & $0.036 \mathrm{abc}$ & 0.029 bcdef \\
\hline $\mathbf{T 1 0}\left(2.5 \mathrm{ml} . \mathrm{bio}^{2}+50 \% \mathrm{NPK}\right)$ & $0.18 \mathrm{abc}$ & 0.206 defg & $0.038 \mathrm{abc}$ & $0.036 a b c$ \\
\hline T11 (2.5 ml. bio ${ }^{3}+50 \%$ NPK $)$ & $0.179 \mathrm{abc}$ & $0.253 \mathrm{bcd}$ & $0.053 \mathrm{ab}$ & 0.030 bcde \\
\hline T12 (2.5 ml. bio $^{4}+50 \%$ NPK $)$ & $0.200 \mathrm{ab}$ & 0.274 bcde & $0.039 \mathrm{abc}$ & $0.037 \mathrm{abc}$ \\
\hline T13 (1.25 ml.bio $^{1}+75 \%$ NPK $)$ & $0.166 \mathrm{abcd}$ & $0.255 \mathrm{bcd}$ & $0.044 \mathrm{abc}$ & $0.037 \mathrm{ab}$ \\
\hline T14 (1.25 ml.bio ${ }^{2}+75 \%$ NPK $)$ & $0.199 \mathrm{ab}$ & 0.224 cdef & $0.038 \mathrm{abc}$ & 0.029 bcdef \\
\hline T15 (1.25 ml.bio ${ }^{3}+75 \%$ NPK $)$ & $0.173 \mathrm{abc}$ & $0.292 \mathrm{ab}$ & $0.053 \mathrm{ab}$ & $0.034 \mathrm{abcd}$ \\
\hline 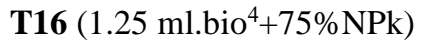 & $0.199 \mathrm{ab}$ & 0.245 bcde & $0.038 \mathrm{abc}$ & $0.036 \mathrm{abc}$ \\
\hline
\end{tabular}

${ }^{1}$ once ${ }^{2}$ twice ${ }^{3}$ three times ${ }^{4}$ four times first addition was a month after sowing, and a month separates the addition and another.

*bio-fertilizer.

Numbers followed by the same letter in the same columns are not significantly different at 5\% DMRT.

growth (Wani et al 2016). However, using Azotobacter alone with adding organic fertilizer gave the highest yield components and growth of fennel (Youssef et al 2020), and gave the highest seed yield on coriander (Hooda and Tehlan 2014) and cumin (Mehta et al 2012). When added Azotobacter with other strains and using $50 \%$ of chemical fertilizer enhanced plant growth and fruits yield of fennel (Ghazal and Shahhat 2012, Dadkhah 2014), dill (Elsayed et al 2020). Moreover, added it with $75 \%$ NPK gave the same results on fennel (Mady 2020), and using it with other strains enhanced vegetative growth and yield on fennel (Shahmohammadi et al 2014), dill (Hellal et al 2011), and cumin (Abdel-Kader et al 2016).

It is well known that phosphorus is essential for all cellular metabolic processes, and it is a basic structure component of numerous biomolecules like Nucleic acids of genes and chromosomes and important in membrane structure, nucleotides, coenzymes, and phosphoproteins and high energy compounds such as ATP and NADPH. (Mengel and Kirkby 2001, Barker and Pilbeam 2015) and by enhanced in hormones activity like cytokinin and gibberellin which influencing ion transport, lead to stomatal opening and regulating the chlorophyll (Allen et al 1982) and the increment of $\mathrm{P}$ content maybe due to applying vesicular-arbuscular mycorrhiza (VAM) which making an extend hyphae into the soil and absorption phosphorus from soil then transfer it along the hyphae through arbuscules to the cortical of root cells (Barea 1991) and provides a large surface area and makes the plant able to reach a larger soil volume for nutrients acquisition and water to the external root surface. Moreover, inoculation plants with VAM elevate photosynthetic rates by enhancing the uptake of phosphorus (Aggarwal et al 2011). Increased the content of $P$ by using VAM was mentioned by (Kapoor et al 2004, Hassan et al 2018) in fennel shoots and fruits and combined them with chemical fertilizer gave the same result on fennel (Dadkhah 2012), coriander (Bastami and Majidian 2016) and Basil (Hasan and Rabie 2019).

Data in Table 5 indicate that the addition of 3.75 $\mathrm{ml}$. bio-fertilizer mixture added four times $+25 \%$ NPK leads to the highest Potassium uptake rate for the first and the second season, and in the second season the addition of $2.5 \mathrm{ml}$. bio-fertilizer added three times+50\%NPK showed non-significant difference between them. The addition of $5 \mathrm{ml}$. of bio-fertilizer only leads to the lowest Potassium uptake rate in both seasons with a non-significant difference between the numbers of additions. 
Table 5. Effect of inoculation with Azotobacter chroococcum, Bacillus circulans and VAM per pot either separate or in combination with chemical fertilizer on Potassium uptake ( $\mathrm{Mg} \mathrm{g}^{-1} \mathrm{dry}$ ) weight of fennel, during 2018/2019 and 2019/2020 seasons

\begin{tabular}{|c|c|c|}
\hline \multirow{2}{*}{ Treatments } & \multicolumn{2}{|c|}{ Potassium uptake $\mathrm{Mg} \mathrm{g}^{-1}$ dry weight } \\
\hline & 2018/2019 & $2019 / 2020$ \\
\hline Control (100\% NPK) & 0.238 defg & 0.291 cde \\
\hline T1 (5 ml.bio $\left.{ }^{* 1}\right)$ & $0.220 \mathrm{efg}$ & $0.197 \mathrm{f}$ \\
\hline $\mathbf{T} 2\left(5 \mathrm{ml} . \mathrm{bio}^{2}\right)$ & $0.186 \mathrm{~g}$ & 0.243 ef \\
\hline T3 $\left(5 \mathrm{ml} \cdot \mathrm{bio}^{3}\right)$ & $0.152 \mathrm{~g}$ & $0.195 \mathrm{f}$ \\
\hline $\mathbf{T 4}\left(5 \mathrm{ml} . \mathrm{bio}^{4}\right)$ & $0.216 \mathrm{fg}$ & $0.182 \mathrm{f}$ \\
\hline T5 (3.75 ml. bio ${ }^{1}+25 \%$ NPK $)$ & $0.355 \mathrm{abc}$ & $0.342 \mathrm{abcd}$ \\
\hline T6 (3.75 ml. bio ${ }^{2}+25 \%$ NPK) & 0.273 bcdef & 0.280 bcde \\
\hline T7 $\left(3.75 \mathrm{ml} . \mathrm{bio}^{3}+25 \%\right.$ NPK $)$ & $0.376 \mathrm{abc}$ & $0.390 \mathrm{ab}$ \\
\hline T8 (3.75 ml. bio $^{4}+25 \%$ NPK) & $0.408 \mathrm{a}$ & $0.412 \mathrm{a}$ \\
\hline T9 $\left(2.5 \mathrm{ml} . \mathrm{bio}^{1}+50 \% \mathrm{NPK}\right)$ & $0.342 \mathrm{abcd}$ & 0.314 bcde \\
\hline T10 (2.5 ml. bio $^{2}+50 \%$ NPK $)$ & $0.337 \mathrm{abcd}$ & $0.390 \mathrm{ab}$ \\
\hline T11 (2.5 ml. bio ${ }^{3}+50 \%$ NPK $)$ & $0.386 \mathrm{abc}$ & $0.407 \mathrm{a}$ \\
\hline T12 $\left(2.5 \mathrm{ml} . \mathrm{bio}^{4}+50 \% \mathrm{NPK}\right)$ & $0.363 \mathrm{abc}$ & $0.362 \mathrm{abcd}$ \\
\hline T13 (1.25 ml. bio ${ }^{1}+75 \%$ NPK $)$ & $0.267 \mathrm{cdef}$ & $0.289 \mathrm{de}$ \\
\hline T14 (1.25 ml. bio ${ }^{2}+75 \%$ NPK $)$ & $0.342 \mathrm{abcd}$ & $0.332 \mathrm{abcd}$ \\
\hline T15 (1.25 ml. bio $^{3}+75 \%$ NPK $)$ & 0.327 abcde & $0.378 \mathrm{abc}$ \\
\hline T16 $\left(1.25 \mathrm{ml} . \mathrm{bio}^{4}+75 \%\right.$ NPK $)$ & $0.345 \mathrm{abcd}$ & $0.329 \mathrm{abcd}$ \\
\hline
\end{tabular}

${ }^{1}$ once ${ }^{2}$ twice ${ }^{3}$ three times ${ }^{4}$ four times first addition was a month after sowing, and a month separates the addition and another.

*bio-fertilizer.

Numbers followed by the same letter in the same columns are not significantly different at 5\% DMRT.

The obtained data could be explained through that the potassium uptake increasing maybe because of Bacillus circulans which is one of the Potassium-Solubilizing Microorganisms which increase production of low molecular weight organic acids like citric, tartaric, and oxalic acids which lead to a decrease of $\mathrm{p}^{\mathrm{H}}$ of the soil and providing protons and chelation the cation bound to potassium which increased the solubility of potassium compounds, also by complexion $\mathrm{Ca}^{2+}$ and other ions in silicate minerals of the soil. Moreover, mucilaginous capsules production by these microorganisms consists of exo-polysaccharides (Groudev 1987) with organic acid leads to illite and feldspar solubility to potassium releasing (Sheng and He 2006). Polysaccharides absorb these organic acids, causing them to attach to the surface of the mineral and as a result, the concentration of organic acids near the metal increases (Liu et al 2006). Biofilms produced by bacteria is formed at the immediate vicinity of minerals and consists of organic acids, polysaccharides and protein thus, accelerated the process of weathering and by form a protective layer covering the min- eral-water-hyphal/root hair that enhanced the weathering of potassium-rich shale and the release of potassium, $\mathrm{Si}$, and Aluminum in the rhizosphere when biofilm formation on the mineral surface (Man et al 2014). Increased seed yield when inoculation Bacillus circulans to anise plant reported by (Darzi et al 2012) although this didn't show a significant effect on plant height and 1000 seeds weight, and when (Azzaz et al 2009) mixed Bacillus circulans with Azotobacter sp., and Bacillus megatherium enhanced plant growth, chemical composition, and volatile oil yield of fennel.

Data in Table 6 indicated that the different fertilization treatments had positive effect on essential oil \% in the first and the second season, the addition of the full recommended dose of NPK gave the highest percentage of essential oil followed by the inoculation of $3.75 \mathrm{ml}$. bio added four times $+25 \%$ NPK with no significant difference between them in both seasons. The addition of $5 \mathrm{ml}$. of bio-fertilizer only gave the lowest percentage of essential oil in both seasons with no significant difference between the numbers of additions. 
Table 7. Effect of inoculation with Azotobacter chroococcum, Bacillus circulans and VAM per pot either separate or in combination with chemical fertilizer on the main constituents of essential oil of fennel, during 2018/2019 season

\begin{tabular}{|c|c|c|c|c|c|}
\hline \multirow{2}{*}{ Treatments } & \multicolumn{5}{|c|}{ Concentration of compounds (\%) } \\
\hline & $\alpha$ - Pinene & Limonene & 1.8 Cineol & Estragole & Anethol \\
\hline Control (100\% NPK) & 2.90 & 18.59 & 10.60 & 68.61 & 1.77 \\
\hline T1 (5 ml.bio $\left.{ }^{* 1}\right)$ & 2.01 & 16.10 & 6.19 & 73.20 & 1.74 \\
\hline $\mathbf{T} 2\left(5 \mathrm{ml} . \mathrm{bio}^{2}\right)$ & 1.98 & 12.69 & 2.04 & 75.01 & 8.26 \\
\hline $\mathbf{T 3}\left(5 \mathrm{ml}^{\mathrm{bio}}{ }^{3}\right)$ & 0.78 & 14.78 & 1.87 & 81.40 & 0.66 \\
\hline T4 $\left(5 \mathrm{ml}^{\mathrm{b}} \mathrm{bio}^{4}\right)$ & 1.92 & 12.46 & 2.38 & 72.43 & 8.02 \\
\hline T5 (3.75 ml. bio $^{1}+25 \%$ NPK $)$ & 1.15 & 10.45 & 2.28 & 72.78 & 12.77 \\
\hline T6 (3.75 ml. bio $^{2}+25 \%$ NPK) & 1.31 & 14.51 & 4.63 & 77.94 & 0.61 \\
\hline T7 (3.75 ml. bio $^{3}+25 \%$ NPK $)$ & 1.28 & 7.40 & 4.70 & 83.37 & 0.26 \\
\hline T8 (3.75 ml. bio $^{4}+25 \%$ NPK $)$ & 0.77 & 13.94 & 1.92 & 80.78 & 0.65 \\
\hline T9 (2.5 ml. bio ${ }^{1}+50 \%$ NPK) & 2.28 & 12.04 & 4.64 & 79.72 & 0.21 \\
\hline T10 $\left(2.5 \mathrm{ml} . \mathrm{bio}^{2}+50 \% \mathrm{NPK}\right)$ & 1.48 & 17.66 & 2.40 & 77.11 & 0.20 \\
\hline T11 $\left(2.5 \mathrm{ml} . \mathrm{bio}^{3}+50 \% \mathrm{NPK}\right)$ & 0.93 & 20.58 & 1.62 & 76.40 & 0.21 \\
\hline T12 $\left(2.5 \mathrm{ml} . \mathrm{bio}^{4}+50 \% \mathrm{NPK}\right)$ & 1.34 & 11.05 & 2.23 & 72.42 & 11.97 \\
\hline T13 (1.25 ml. bio $+75 \%$ NPK) & 0.72 & 16.72 & 6.83 & 75.40 & 0.14 \\
\hline T14 (1.25 ml. bio $^{2}+75 \%$ NPK $)$ & 0.88 & 12.46 & 2.41 & 76.28 & 0.49 \\
\hline T15 (1.25 ml. bio $3+75 \%$ NPK $)$ & 1.90 & 14.15 & 2.43 & 78.33 & 0.44 \\
\hline T16 (1.25 ml. bio $+75 \%$ NPK $)$ & 1.26 & 14.21 & 4.61 & 78.99 & 0.52 \\
\hline
\end{tabular}

${ }^{1}$ once $^{2}$ twice ${ }^{3}$ three times ${ }^{4}$ four times first addition was a month after sowing, and a month separates the addition and another.

*bio-fertilizer.

Table 8. Effect of inoculation with Azotobacter chroococcum, Bacillus circulans and VAM per pot either separate or in combination with chemical fertilizer on Total microbial count $\left(\times 10^{4} / \mathrm{g}\right.$ soil) and cumulative $\mathrm{CO}_{2}-\mathrm{C}\left(\mathrm{mg} \mathrm{C} \mathrm{g}^{-1}\right.$ soil) of fennel, during 2018/2019 and 2019/2020 seasons

\begin{tabular}{|c|c|c|c|c|}
\hline \multirow{2}{*}{ Treatments } & \multicolumn{2}{|c|}{ Total microbial count $\left(\times 10^{4} / g\right.$ soil $)$} & \multicolumn{2}{|c|}{ Cumulative $\mathrm{CO}_{2}-\mathrm{C}\left(\mathrm{mg} \mathrm{C}^{-1}\right.$ soil $)$} \\
\hline & 2018/2019 & $2019 / 2020$ & $2018 / 2019$ & $2019 / 2020$ \\
\hline Control (100\% NPK) & $21.5 \mathrm{~m}$ & $24.75 \mathrm{~m}$ & $0.002 \mathrm{~m}$ & $0.003 \mathrm{i}$ \\
\hline T1 $\left(5\right.$ ml.bio $\left.^{* 1}\right)$ & $54.5 \mathrm{i}$ & $51.25 \mathrm{i}$ & $0.0102 \mathrm{~h}$ & $0.0105 \mathrm{f}$ \\
\hline $\mathbf{T} 2\left(5 \mathrm{ml}^{\mathrm{bio}}{ }^{2}\right)$ & $60.75 \mathrm{~h}$ & $66.5 \mathrm{f}$ & $0.0106 \mathrm{gh}$ & $0.0108 \mathrm{f}$ \\
\hline T3 $\left(5 \mathrm{ml} \cdot \mathrm{bio}^{3}\right)$ & $66.5 \mathrm{f}$ & $61 \mathrm{~h}$ & $0.0125 \mathrm{e}$ & $0.0120 \mathrm{e}$ \\
\hline T4 $\left(5 \mathrm{ml}^{\mathrm{b}} \mathrm{bio}^{4}\right)$ & $86.5 \mathrm{c}$ & $73 \mathrm{e}$ & $0.0163 \mathrm{~d}$ & $0.0192 \mathrm{c}$ \\
\hline T5 (3.75 ml.bio ${ }^{1}+25 \%$ NPK $)$ & $65.5 \mathrm{fg}$ & $63.5 \mathrm{~g}$ & $0.0175 \mathrm{c}$ & $0.0184 \mathrm{c}$ \\
\hline T6 (3.75 ml.bio ${ }^{2}+25 \%$ NPK $)$ & $81.5 \mathrm{~d}$ & $114 \mathrm{c}$ & $0.0198 \mathrm{~b}$ & $0.0120 \mathrm{e}$ \\
\hline T7 (3.75 ml.bio $+25 \%$ NPK $)$ & $91.25 \mathrm{~b}$ & $125.25 \mathrm{~b}$ & $0.0203 \mathrm{~b}$ & $0.0213 \mathrm{~b}$ \\
\hline T8 (3.75 ml.bio $4+25 \%$ NPK) & $114.5 \mathrm{a}$ & $140.75 \mathrm{a}$ & $0.0224 \mathrm{a}$ & $0.02635 \mathrm{a}$ \\
\hline T9 (2.5 ml.bio $^{1}+50 \%$ NPK $)$ & $46.5 \mathrm{j}$ & 33.51 & $0.0107 \mathrm{gh}$ & $0.0108 \mathrm{f}$ \\
\hline T10 $\left(2.5 \mathrm{ml} . \mathrm{bio}^{2}+50 \% \mathrm{NPK}\right)$ & $63.25 \mathrm{gh}$ & $45.5 \mathrm{j}$ & $0.0113 \mathrm{fg}$ & 0.0112 ef \\
\hline T11 $\left(2.5 \mathrm{ml} . \mathrm{bio}^{3}+50 \% \mathrm{NPK}\right)$ & $67 \mathrm{f}$ & $71.5 \mathrm{e}$ & $0.0117 \mathrm{ef}$ & $0.0132 \mathrm{~d}$ \\
\hline T12 $\left(2.5\right.$ ml.bio $^{4}+50 \%$ NPK $)$ & $72.5 \mathrm{e}$ & $83.5 \mathrm{~d}$ & $0.0173 \mathrm{c}$ & $0.0136 \mathrm{~d}$ \\
\hline $\mathbf{T 1 3}\left(1.25\right.$ ml.bio ${ }^{1}+75 \%$ NPK$)$ & 31.751 & $26 \mathrm{~m}$ & $0.0075 \mathrm{i}$ & $0.0035 \mathrm{i}$ \\
\hline T14 (1.25 ml.bio ${ }^{2}+75 \%$ NPK $)$ & 311 & $26.5 \mathrm{~m}$ & $0.0045 \mathrm{k}$ & $0.0065 \mathrm{~h}$ \\
\hline $\mathbf{T 1 5}\left(1.25 \mathrm{ml}^{\mathrm{bio}}{ }^{3}+75 \% \mathrm{NPK}\right)$ & 32.51 & 34.51 & 0.00351 & $0.008 \mathrm{~g}$ \\
\hline T16 (1.25 ml.bio ${ }^{4}+75 \%$ NPK $)$ & $41.5 \mathrm{k}$ & $42.75 \mathrm{k}$ & $0.0057 \mathrm{j}$ & $0.0082 \mathrm{~g}$ \\
\hline
\end{tabular}

${ }^{1}$ once $^{2}$ twice ${ }^{3}$ three times ${ }^{4}$ four times first addition was a month after sowing, and a month separates the addition and another.

"bio-fertilizer.

Numbers followed by the same letter in the same columns are not significantly different at 5\% DMRT. 
According to the previous results, it appears that after the addition of bio-fertilizers to the soil, these strains have been able to adapt to fennel plant rhizosphere and increased their reproduction and their vital activities and this maybe led to an increase in the microbial population in the rhizosphere and therefore total microbial count. This may be due to the production of melanin which is a dark-brown water-soluble produced by Azotobacter chroococcum on the processes of nitrogen fixation (Shivprasad and Page 1989) which are involved in the metabolism of microbial organisms and improved the microbial activity in soils (Hajnal-Jafari et al 2012). Furthermore, there is a close relationship between the biological activities of soil microorganisms and its number, so we can used estimation of the value of emitted $\mathrm{CO}_{2}$ during the respiration process of soil microorganism as an index for the soil microbial respiration (Parastesh et al 2019, Smitha et al 2019).

Increased cumulative $\mathrm{CO}_{2}-\mathrm{C}$ might be due to the Enhancement of microbial communities on the rhizosphere which stimulation of microbial activities, and it agrees with (Awad et al 2013). Moreover, it enhances the physical properties of the soil, which leads to an increase in the rate of respiration of microbes (Jones et al 2011). The increment of biomass carbon and soil microbial respiration in response to the application of bio-fertilizers reported by (Parastesh et al 2019, Dehsheikh et al 2020) and under sandy soil conditions (Zaki et al 2010) indicate that the addition of bio-fertilizer increased total microbial count.

\section{Conclusions}

The addition of bio-fertilizers Azotobacter chroococcum $\left(10^{8}\right.$ CFU), Bacillus circulans $\left(10^{8}\right.$ CFU), and VAM (200 spores) enhanced plant rhizospher and microbial activity for the fennel root, which leads to increased nitrogen, phosphorus and potassium uptake and thus increased vegetative growth, enhanced the essential oil percentage and its component. And from the overall results, we recommend that the addition of $3.75 \mathrm{ml}$. of biofertilizer mixture (Azotobacter chroococcum, Bacillus circulans, and VAM) four times with $25 \%$ of the recommended dosage of chemical fertilizer can enhance the productivity of fennel.

\section{References}

Aasfar A, Bargaz A, Yaakoubi K, Hilali, Bennis I, Zeroual Y, Kadmiri IM (2021) nitrogen fixing Azotobacter species as potential soil biological enhancers for crop nutrition and yield stability. Frontiers of Microbiology 12, 1-19. https://doi.org/10.3389/fmicb.2021.628379

Abdel-Kader AAS, Saleh FEM, Ragab AA (2016) effect of organic manure and bio-fertilizers on productivity and quality of cumin (Cuminum cyminum, L.) plant grown in calcareous sandy soil. Assiut Journal of Agricultural Sciences 47, 473-483. https://doi.org/10.21608/ajas.2016.2760

Abdel Wahab MM, El-Attar AB, Shehata SA (2016) boosting fennel plant yield and components using combination of manure, compost and biofertilizers. Arabian Journal of Medicinal and Aromatic Plants Boosting 2, 28-36.

https://doi.org/10.48347/IMIST.PRSM/ajmap$\underline{\mathrm{v} 2 \mathrm{i} 1.4858}$

Aggarwal A, Kadian N, Tanwar A, Yadav A, Gupta KK (2011) role of arbuscular mycorrhizal fungi (AMF) in global sustainable development. Journal of Applied and Natural Science 3, 340-351.

https://doi.org/10.31018/jans.v3i2.211

Allen MF, Moore TS, Christensen M (1982) phytohormone changes in altered levels of gibberellinlike substances and abscisic acid in the as affected by vesicular- arbuscular mycorrhizae. Plant Soil 121130.

Awad YM, Blagodatskaya E, Ok YS, Kuzyakov Y (2013) effects of polyacrylamide, biopolymer and biochar on the decomposition of ${ }^{14} \mathrm{C}$-labelled maize residues and on their stabilization in soil aggregates. European Journal of Soil Science 64, 488-499. https://doi.org/10.1111/ejss.12034

Azzaz NA, Hassan EA, Hamad EH (2009) the chemical constituent and vegetative and yielding characteristics of fennel plants treated with organic and bio-fertilizer instead of mineral fertilizer. Australian Journal of Basic and Applied Sciences 3, 579-587.

Babalola OO (2010) beneficial bacteria of agricultural importance. Biotechnology Letters 32, 1559-1570.

https://doi.org/10.1007/s10529-010-0347-0 
Barabasz W, Albińska D, Jaśkowska M, Lipiec J (2002) biological effects of mineral nitrogen fertilization on soil microorganisms. Polish Journal of Environmental Studies 3, 193-198.

Barea JM (1991) vesicular-arbuscular mycorrhizae as modifiers of soil fertility, in: Stewart BA (Ed.), advances in soil science. Springer New York pp. 1-40.

https://doi.org/10.1007/978-1-4612-3030-4_1

Barker AV, Pilbeam DJ (Eds.) (2015) handbook of plant nutrition. CRC Press Taylor \& Francis Group pp. 17-127.

Bastami A, Majidian M (2016) comparison between mycorrhizal fungi, phosphate biofertilizer and manure application on growth parameters and dry weight of coriander (Coriandrum sativum L.) medicinal plant. Journal of Science and Technology of Greenhouse Culture 7, 23-33. DOI:10.18869/acadpub.ejgcst.7.2.23

Bunt JS, Rovira AD (1955) microbiological studies of some subantarctic soils. Journal of Soil Science 6, 119-128.

https://doi.org/10.1111/j.1365-

2389.1955.tb00836.x

Chapman HD, Pratt PF (1961) methods of plant analysis for soils, plants and water. University of California, Los Angelespp 150-179.

Da-Costa PB, Beneduzi A, De-Souza R, Schoenfeld R, Vargas LK, Passaglia LMP (2013) the effects of different fertilization conditions on bacterial plant growth promoting traits: guidelines for directed bacterial prospection and testing. Plant Soil 368, 267-280.

https://doi.org/10.1007/s11104-012-1513-z

Dadkhah A (2012) effect of chemicals and biofertilizers on yield, growth parameters and essential oil contents of funnel (Foeniculum vulgare Miller.). Journal of Medicinal Plants and By-products 2, 101-105.

Dadkhah A (2014) effect of some plant growth promoting rhizobacteria and chemical fertilizer on growth parameters, yield and essential oil of fennel (Foeniculum vulgare Mill). Zeitschrift für Arznei-Gewürzplanzen 19, 118-122.

Darzi MT, Seyedhadi MH, Rejali F (2012) effects of the application of vermicompost and phosphate solubilizing bacterium on the morphological traits and seed yield of anise (Pimpinella anisum L.). Journal of Medicinal Plants Research 6, 215-219.
Dehsheikh AB, Sourestani MM, Zolfaghari M, Enayatizamir N (2020) changes in soil microbial activity, essential oil quantity, and quality of Thai basil as response to biofertilizers and humic acid. Journal of Cleaner Production 256, 1-10.

https://doi.org/10.1016/j.jclepro.2020.120439

Dhifi W, Bellili S, Jazi S, Bahloul N, Mnif W (2016) essential oils' chemical characterization and investigation of some biological activities. Medicines 3, 25. https://doi.org/10.3390/medicines3040025

Ebeed NM, Abdou HS, Booles HF, Salah SH, Ahmed ES, Fahmy K (2010) antimutagenic and chemoprevention potentialities of sweet fennel (Foeniculum vulgare Mill.) hot water crude extract. Journal of American Science Sci 6, 831-842.

El-Azim AWM, Khater Rania MR, Badawy MYM (2017) effect of bio-fertilization and different licorice extracts on growth and productivity of Foeniculum vulgare, Mill. Middle East Journal of Agriculture 6, $1-12$.

https://www.curresweb.com/mejar/mejar/2017/1-12.pdf

Elsabawy, MNE (2012) Medicinal And Aromatic Crops In Egypt: A Study In Medical Geography. J Educ Soc Res 2, 112-124.

https://doi.org/10.5901/jesr.2012.v2n9p112

Elsayed SIM, Glala AA, Abdalla AM, El-Sayed AEGA, Darwish MA (2020) effect of biofertilizer and organic fertilization on growth, nutrient contents and fresh yield of dill (Anethum graveolens). Bulletin of the National Research Centre 44, 1-10.

https://doi.org/10.1186/s42269-020-00375-z

Ghazal GMEM, Shahhat IMAM (2012) physiological and phytochemical responses of Foeniculumvulgare var. vulgare Mill. and Foeniculum vulgare var. azoricum Mill. to bio-organic manure as partial or full substitute for inorganic amendment. Australian Journal of Basic and Applied Sciences 6, 266-277.

González-López J, Rodelas B, Pozo C, SalmerónLópez V, Martínez-Toledo MV, Salmerón V (2005) liberation of amino acids by heterotrophic nitrogen fixing bacteria. Amino Acids 28, 363-367.

https://doi.org/10.1007/s00726-005-0178-9

Good AG, Beatty PH (2011) fertilizing nature: a tragedy of excess in the commons. Plos Biology 9, 19. https://doi.org/10.1371/journal.pbio.1001124

Groudev SN (1987) Use of heterotrophic microorganisms in mineral biotechnology. Acta Biotechnological 7, 299-306. https://doi.org/10.1002/abio.370070404 
Hajnal-Jafari T, Latkovic D, Đuric S, Mrkovacki N, Najdenovska O (2012) the use of Azotobacter in organic maize production. Research Journal of Agricultural Science 44, 28-32.

Hasan IA, Rabie KM (2019) effect of organic and bio-fertilization on the vegetatlve yleld for two cultivars of basil plant. Plant Archives 19, 415423.

Hassan EA, Hamad ESHA, Ibrahim AE, Khalil RAA (2018) impact of rock phosphate sources and their solubility by some microorganisms on Carum carvi plants productivity. Middle East Journal of Applied Sciences 08, 787-797.

Hayat R, Ali S, Amara U, Khalid R, Ahmed I (2010) soil beneficial bacteria and their role in plant growth promotion: a review. Annals of Microbiology 60, 579-598.

https://doi.org/10.1007/s13213-010-0117-1

Hellal FA, Mahfouz SA, Hassan FAS (2011) partial substitution of mineral nitrogen fertilizer by bio-fertilizer on (Anethum graveolens L.) plant. Agriculture and Biology Journal of North America 2, 652-660.

https://doi.org/10.5251/abjna.2011.2.4.652.660

HoodaV, Tehlan SK (2014) effect of biofertilizers, FYM and nitrogen levels on seed yield and seed quality of coriander (Coriandrum sativum L.). Annals of Agri Bio Research 19, 121123.

Jones DL, Murphy DV, Khalid M, Ahmad W, Edwards-Jones G, Deluca TH (2011) short-term biochar-induced increase in soil $\mathrm{CO} 2$ release is both biotically and abiotically mediated. Soil Biology and Biochemistry 43, 1723-1731. https://doi.org/10.1016/j.soilbio.2011.04.018

Kalayu G (2019) phosphate solubilizing microorganisms: promising approach as biofertilizers. International Journal of Agronomy 1-7. https://doi.org/10.1155/2019/4917256

Kapoor R, Giri B, Mukerji KG (2004) improved growth and essential oil yield and quality in Foeniculum vulgare Mill on mycorrhizal inoculation supplemented with P-fertilizer. Bioresource Technology 93, 307-311.
Khalil HMA, Abo-Basha DMR, El-Agyzy FHA (2018) effect of Bacillus circulans bacteria on availability of potassium from different sources on the productivity and quality of pepper under saline soil conditions. Middle East Journal of Applied Sciences 7, 339-351.

Lim TK (2013) Foeniculum vulgare, in: edible medicinal and non-medicinal plants. Springer Netherlands pp. 36-59.

https://doi.org/10.1007/978-94-007-5653-3 4

Liu W, Xu X, Wu X, Yang Q, Luo Y, Christie P (2006) decomposition of silicate minerals by Bacillus mucilaginosus in liquid culture. Environmental Geochemistry and Health 28, 133-140.

https://doi.org/10.1007/s10653-005-9022-0

Mady MAAY (2020) improvement of the productiiviity and qualliity of mediiciinall and aromatiic plants for export. Ms in Horticulture, Horticulture Dept Faculty of Agriculture Benha University.

Mahato P, Badoni A, Chauhan JS (2009) effect of Azotobacter and nitrogen on seed germination and early seedling growth in tomato. Researcher 1, 62-66. Man LY, Cao XY, Sun DS (2014) effect of potassiumsolubilizing bacteria-mineral contact mode on decomposition behavior of potassium-rich shale. Chinese Journal of Nonferrous Metals 24, 48-52.

Massoud H (1992) study on the essential oil in seeds of some fennel cultivars under egyptian environmental conditions, in: Planta Medica pp. 681-682.

https://doi.org/10.1055/s-2006-961700

Massoud HYA, Dawa KK, Gamal SMA, EL-Karkash SHA (2019) response of (Petroselinum sativum Hoffm.) to organic, bio-fertilizer and some foliar application. Journal of Plant Production 10, 1194 1161. DOI:10.21608/jpp.2019.77952

Mehta RS, Anwer MM, Malhotra SK (2012) influence of sheep manure, vermicompost and biofertilizer on growth, yield and profitability of cumin (Cuminum cyminum L.) production. Journal of Spices and Aromatic Crops 21, 16-19.

Mengel K, Kirkby EA (2001) principles of plant nutrition, $5^{\text {th }}$ ed. Kluwer Academic Publishcrs pp. 453-477. DOI:10.1093/aob/mch063 
Mohammadi K, Sohrabi Y (2012) bacterial biofertilizers for sustainable crop production: a review. ARPN Journal of Agricultural and Biological Science 7, 307-316.

Nurzyńska-Wierdak R (2013) does mineral fertilization modify essential oil content and chemical composition in medicinal plants. Acta Scientiarum Polonorum, Hortorum Cultus 12, 316.

Okalebo JR, Gathua KW, Woomer PL (2002) total nitrogen and phosphorus in plants and soils: a working manual, $2^{\text {nd }}$ ed, Sacred Africa, Nairobi, pp. 29-35.

Osman YAH (2009) comparative study of some agricultural treatments effects on plant growth, yield and chemical constituents of some fennel varieties under sinai conditions. Research Journal of Agriculture and Biological Sciences 5, 541554.

Padhan D, Sen A, Adhikary S, Kundu R, Yadav VK (2019) potassium solubilisation in soils: mechanisms, effect on plant growth and future prospects in: current research in soil fertility, volume 1,Akinik, New Delhi pp. 39-59.

https://doi.org/10.22271/ed.book.437

Parastesh F, Alikhani HA, Etesami H (2019) vermicompost enriched with phosphatesolubilizing bacteria provides plant with enough phosphorus in a sequential cropping under calcareous soil conditions. Journal of Cleaner Production 221, 27-37.

https://doi.org/10.1016/j.jclepro.2019.02.234

Pharmacopoeia B (1963) determination of volatile oil in drugs, in: the pharmaceutical press. london, pp. $220-222$.

Prajapati K, Yami KD, Singh A (2008) plant growth promotional effect of Azotobacter chroococcum, Piriformospora indica and vermicompost on rice plant. Nepal Journal of Science and Technology 9, 85-90.

https://doi.org/10.3126/njst.v9i0.3170

Roshanpour N, Darzi MT, Hadi MHS (2014) quantity and quality of essential oil of basil (Ocimum basilicum L.) under biofertilizers application conditions. International journal of Advanced Biological and Biomedical Research 2, 2134-2142.
Sajjadnia N, Mirshekari B, Amirnia R (2013) sustainable production of fennel (Foeniculum vulgare Mill.) by seed inoculation with mycorrhizae strains under drought stress conditions. International Journal of Biosciences 3, 169-174.

Shahmohammadi F, Darzi MT, Hadi MHS (2014) influence of compost and biofertilizer on yield and essential oil of dill (Anethum graveolens L.). International journal of Advanced Biological and Biomedical Research 2, 446-455

Sharma NK, Singh RJ, Kumar K (2012) dry matter accumulation and nutrient uptake by wheat (Triticum aestivum L.) under poplar (Populus deltoides) based agroforestry system. ISRN Agronomy 2012, 1-7. https://doi.org/10.5402/2012/359673

Sharma SB, Sayyed RZ, Trivedi MH, Gobi TA (2013) phosphate solubilizing microbes: sustainable approach for managing phosphorus deficiency in agricultural soils. Springerplus 2, 1-14.

https://doi.org/10.1186/2193-1801-2-587

Sheng XF, He LY (2006) solubilization of potassiumbearing minerals by a wild-type strain of Bacillusedaphicus and its mutants and increased potassium uptake by wheat. Canadian Journal of Microbiology 52, 66-72.

https://doi.org/10.1139/w05-117

Shivprasad S, Page WJ (1989) catechol formation and melanization by $\mathrm{Na}+$ dependent Azotobacter chroococcum: a protective mechanism for aeroadaptation. Applied and Environmental Microbiology 55, 1811-1817.

https://www.ncbi.nlm.nih.gov/pmc/articles/PMC2029 $\underline{55 /}$

Simpson RJ, Oberson A, Culvenor RA, Ryan MH, Veneklaas EJ, Lambers H, Lynch JP, Ryan PR, Delhaize E, Smith FA, Smith SE, Harvey PR, Richardson AE (2011) strategies and agronomic interventions to improve the phosphorus-use efficiency of farming systems. Plant Soil 349, 89-120. DOI: 10.1007/s11104-011-0880-1

Smitha GR, Basak BB, Thondaiman V, Saha A (2019) nutrient management through organics, bio-fertilizers and crop residues improves growth, yield and quality of sacred basil (Ocimum sanctum Linn). Industrial Crops and Products 128, 599-606.

https://doi.org/10.1016/j.indcrop.2018.11.058 
Trade Map - List of exporters for the selected product in 2019 (Seeds of anis, badian, fennel, coriander, cumin or caraway; juniper berries) URL

https://www.trademap.org/Country SelProduct.as px?nvpm=1\%7C\%7C\%7C\%7C\%7C0909\%7C\%7 $\mathrm{C} \% 7 \mathrm{C} 4 \% 7 \mathrm{C} 1 \% 7 \mathrm{C} 1 \% 7 \mathrm{C} 2 \% 7 \mathrm{C} 1 \% 7 \mathrm{C} \% 7 \mathrm{C} 2 \% 7 \mathrm{C} 1$ $\% 7 \mathrm{C} 1 \% 7 \mathrm{C} 1$

Wani SA, Chand S, Wani MA, Ramzan M, Hakeem KR (2016) Azotobacter chroococcum - a potential biofertilizer in agriculture: an overview, in: soil science: agricultural and environmental prospectives. springer pp. 333-348. https://doi.org/10.1007/978-3-319-34451-5_15

Youssef IA, Ali ME, Noufal EHA, Ismail SA, Ali MME (2020) effect of different sources and levels of nitrogen fertilizers with and without organic and bio- fertilizers on growth and yield components of fennel plants (Foeniculum vulgare Mill.). Asian Journal of Soil Science and Plant Nutrition 6, 6-14. DOI:10.9734/ajsspn/2020/v6i130077

Zaki MF, Abdelhafez AAM, El-Dewiny CY (2010) influence of applying phosphate bio-fertilizers and different levels of phosphorus sources on the productivity, quality and chemical composition of sweet fennel (Foeniculum Vulgare Mill.). Australian Journal of Basic and Applied Sciences 4, 334-347.

Zibilske LM (1994) carbon mineralization, in: methods of soil analysis, part 2: microbiological and biochemical properties,Soil Science Society of America pp. 835-863.

https://doi.org/10.2136/sssabookser5.2.c38 